\title{
Minerals and extremely low birth weight infants
}

\author{
Guglielmo Salvatori", Silvia Foligno \\ From XXI Congress of the Italian Society of Neonatology \\ Palermo, Italy. 24-26 September 2015
}

The $80 \%$ of bone mineralisation occurs in the third trimester of pregnancy. The daily fetal requirement is $310 \mathrm{mg}$ of calcium and $170 \mathrm{mg}$ of phosphorus [1]. The bone mineral density (BMD) correlates positively with gestational age, weight and length [2]. At birth, extremely premature infants (ELBWI)canpresent hypocalcaemia because of interruption of the maternal calcium supply, high level of calcitoninand immature response to PTH. Early parenteral nutrition solutionisnecessary to maintain normal serum calcium and phosphorus levels. Indeed, the exclusive use of dextrose and calcium gluconate leads to thehypophosphatemia, deleterious to intermediary metabolism, intracellular energy transfer and bone mineral homeostasis [3]. The ELBWI are at risk of Osteopenia of prematurity, also known as neonatal metabolic bone disease (MBD). The pathophysiology includesreduction in organic protein matrix (osteopenia) and/or a reduction in mineral component (osteomalacia). MBD causes rickets, fractures and may affect growth in infancy and childhood. The structural basis of osteopenia is decreased thickness or number of trabeculae and/or decreased thickness of the bone cortex. Osteomalaciais a disorder of the physiological process of mineralisation, when the incorporation of mineral into the organic bone matrix is disturbed, whereas "rickets" describes defective mineralisation of growth plate cartilage and its morphological consequences [4]. The ethiology is multifactorial: placental dysfunction, prolonged ( $>4$ weeks) parenteral nutrition, diureticsand steroids treatment, immobilization and inadequate nutrient intake of calcium, phosphorus, and vitamin D [5]. The main ethiology factor is deficit of mineral substrates, whereas the critical factor is lack of phosphorus [4]. It should be needed an adequate mineral supplementation with parenteral and enteral nutrition, although the difficulties to fortify appropriately the human milk. The dosage recommended of vitamin D is between, $400 \mathrm{IU} / \mathrm{d}$ (AAP) and $1000 \mathrm{IU} / \mathrm{d}$ (ESPGHAN)

\footnotetext{
* Correspondence: guglielmo.salvatori@opbg.net

Department of Medical and Surgical Neonatology, Children's Hospital
} Bambino Gesù, IRCSS, Rome,00165, Italy

(c) 2015 Salvatori and Foligno This is an Open Access article distributed under the terms of the Creative Commons Attribution License (http://creativecommons.org/licenses/by/4.0), which permits unrestricted use, distribution, and reproduction in any medium, provided the original work is properly cited. The Creative Commons Public Domain Dedication waiver (http://creativecommons.org/ publicdomain/zero/1.0/) applies to the data made available in this article, unless otherwise stated.

References

1. Sparks JW: Human intrauterine growth and nutrient accretion. Semin Perinatol 1984, 8(2):74-93

2. Salle BL, Braillon P, Glorieux FH, Brunet J, Cavero E, Meunier PJ: Lumbar bone mineral content measured by dual energy X-ray absorptiometry in newborns and infants. Acta Paediatr 1992, 81(12):953-958.

3. Yokoyama Y, Fujioka S, Kato K, Tomono H, Yoshida K, Nimura Y: Primary carcinoid tumor of the gallbladder: resection of a case metastasizing to the liver and analysis of outcomes. Hepatogastroenterology 2000, 47(31):135-139.

4. AM P: Vitamin D and the pathogenesis of rickets and osteomalacia. In Vitamin D. Volume 645?-?62. San Diego: Academic Press;Feldman D GF, Pike W 1997.

5. Abrams SA, Committee on Nutrition: Calcium and vitamin d requirements of enterally fed preterm infants. Pediatrics 2013, 131(5):e 1676-1683.

6. Braegger C, Campoy C, Colomb V, Decsi T, Domellof M, Fewtrell M, Hojsak I, Mihatsch W, Molgaard C, Shamir R, et al: Vitamin D in the healthy European paediatric population. J Pediatr Gastroenterol Nutr 2013, 56(6):692-701.

7. Rodriguez Jl, Garcia-Alix A, Palacios J, Paniagua R: Changes in the long bones due to fetal immobility caused by neuromuscular disease. A radiographic and histological study. The J Bone Joint Surg Am 1988, 70(7):1052-1060

8. Harrison CM, Gibson AT: Osteopenia in preterm infants. ArchDis Child Fetal Neonatal Ed 2013, 98(3):F 272-275.

doi:10.1186/1824-7288-41-S1-A37

Cite this article as: Salvatori and Foligno: Minerals and extremely low birth weight infants. Italian Journal of Pediatrics 2015 41(Suppl 1):A37. 